Copyright (C) 2017 by Academic Publishing House Researcher

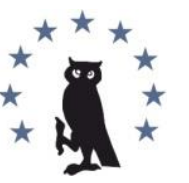

Published in the Russian Federation

European Researcher. Series A

Has been issued since 2010.

ISSN 2219-8229

E-ISSN 2224-0136

2017, 8(2): 70-77

DOI: 10.13187/er.2017.2.70

www.erjournal.ru

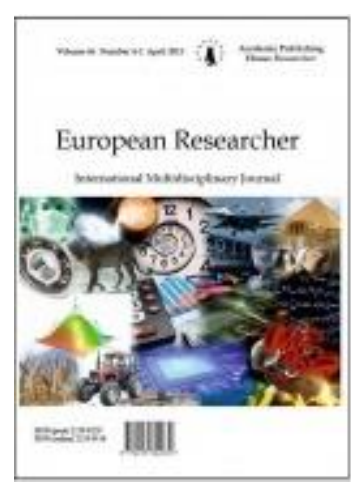

UDC 316.6

\title{
Analysis of Product Buying Decision on Lazada E-commerce based on Previous Buyers' Comments
}

\author{
Neil Aldrin ${ }^{a}{ }^{*}$ \\ a Lecturer, Faculty of Psychology, Bhayangkara Jakarta Raya University, Indonesia
}

\begin{abstract}
The aims of the present research are: 1) to know that product buying decision possibly occurs, 2) to know how product buying decision occurs on Lazada e-commerce's customers, 3) how previous buyers' comments can increase product buying decision on Lazada e-commerce. This research utilizes qualitative research method. Qualitative research is a research that investigates other researches and makes assumption or discussion result so that other analysis results can be made in order to widen idea and opinion. Research result shows that product which has many ratings and reviews will trigger other buyers to purchase or get that product. The conclusion is that product buying decision may occur because there are some processes before making decision which are: looking for recognition and searching for problems, knowing the needs, collecting information, evaluating alternative, evaluating after buying. In those stages, buying decision on Lazada e-commerce is supported by price, promotion, service, and brand.
\end{abstract}

Keywords: comments, buying decision, e-commerce, Lazada

\section{Introduction}

In this modern era, e-commerce business is a business that can grow rapidly. E-commerce business can grow rapidly since it is supported by internet technology that makes e-commerce known widely by people. By the help of internet network, e-commerce product can be enjoyed by all users that are supported by smartphone technology. In the development of e-commerce, it is needed to be supported by strong business strategy in order to be able to compete with other ecommerces. On the other hand, in running e-commerce business, it is needed to keep good relationship with customers in order they do not move to other e-commerce (Best, 2013). It can be done by providing every needs expected by customers, both products and services, which are supported by price, product quality, safety, delivery punctuality, product warranty, discount, voucher, and promo.

E-commerce is a website-based digital market made systematically which has high security level because the transaction is done via online. It is called digital market because all products and brands are shown on website and it only can be seen with supporting devices connected with internet like laptop or Smartphone (Chairunnisa, Irwansyah, 2016). Other opinions state that e-commerce is selling and purchasing goods or services through internet network, (Awais, Samin,

\footnotetext{
${ }^{*}$ Corresponding author

E-mail addresses: dr.neilaldrin@gmail.com (N. Aldrin)
} 
2011). By browsing on internet, customers can find some needed products, started from household items, electronics, fashions, automotive, medicines, and many more.

For customers, it is a benefit to shop on e-commerce because customers do not need to move from their places or wherever they are, they still can do transaction of selling and purchasing. Shopping on e-commerce is easier because products can be chosen based on the expected category and customers can compare prices so that they will get the product with the affordable price. Besides, many e-commerces have warranty and good security like Lazada e-commerce.

Lazada is one of popular e-commerces on internet which has a quite wide market including in Indonesia. Lazada has been known by most of Indonesian's people. Lazada is able to run ecommerce in some countries with various products needed by people generally like fashion, baby items, sport items, electronics, and health items (www.Lazada.co.id). Lazada provides various products with payment method that is easy and its safety is guaranteed. On the other hand, Lazada also offers product return and refund if product is out of stock or product is not like what has been ordered.

Shopping on e-commerce for customers who just do online shop for the first time automatically have worry if the transaction is failed and product is not like what is wanted or broken. It should be noticed that the weaknesses of online shopping are: 1) in accessing ecommerce, stabile internet connection is needed, 2) customers' worry exists if they never use services like afraid of deception, delivered product is broken, and its quality is not good, 3) the wrong e-commerce website selection may lead to deception, 4) payment system is not as easy as cash payment, 5) it needs long time to get the product (Chairunnisa, Irwansyah, 2016).

Before buying products via online, nowadays customers are smart enough to determine their buying decision. Commonly, customers find out regarding to reputation of the e-commerce website. Usually, professional e-commerce website always shows its advertisement on social media or paid advertisement services like google adwords in which in showing its advertisement, ecommerce party must pay to show its advertisement. It is impossible to be done by e-commerce aiming to do deception. On the other hand, customers usually check its service and safety. If it has a good service and safety, the customers will be more interested. The most important element is the buyers' comments when buying products and the products are on the e-commerce website.

From statements that have been elaborated aforementioned, research problems can be made as follows: 1) how can product buying decision occur?, 2) how can buying decision occur on Lazada e-commerce?. 3) how can previous buyers' comments increase product buying decision on Lazada e-commerce?

The aims of the present research are: 1) to know product buying decision possibly occurs, 2) to know how buying decision occurs on Lazada e-commerce's customers, 3) to know how previous buyers' comments can increase product buying decision on Lazada e-commerce.

\section{Theoretical Framework \\ 2.1. Buying Decision}

Analysis on e-commerce product buying decision is to identify elements that make the decision occur. There are five processes of decision making which are as follows: 1) looking for recognition and searching for problems, 2) knowing the needs, 3) collecting information, 4) evaluating alternative, and 5) evaluating after buying (Kotler, Amstrong, 2009). On the other hand, buying decision extremely depends on information availability, website interest, and easiness in doing online transaction (Shim et al., 2002). Trust on transaction and influence on online network affect someone's decision in buying a product (McCole et al., 2010).

\subsection{E-Commerce (Lazada)}

Product selling and purchasing transaction via online with the help of internet connection that can be done globally is called e-commerce (Gao, 2016). Other researchers argue that if selling and purchasing transaction is done by using computer and internet connection, then it is included to e-commerce (Gangeshwer, 2013).

\subsection{Previous Buyers' Comments}

On e-commerce website, all business information is supported by electronic data, electronic mail, electronic bulletin board, and fund transfer electronically on World Wide Web network 
(Bhalekar et al., 2015). From some opinions of experts, it can be concluded that e-commerce is an online selling and purchasing service that utilizes website to show product information and its transaction is supported by internet assistance.

Lazada is e-commerce that has operated in some countries such as Indonesia, Malaysia, Singapura, Thailand, Vietnam, Filipina. Lazada is the pioneer of e-commerce in some countries with the fastest growth in the world offering fast, safe, and comfortable online shopping with products category started from fashion, household items, electronic utilities, children toys, and sport items (www.Lazada.co.id).

\section{Research Method}

This present research is included to a qualitative research. Qualitative research is a research that investigates other researches and makes assumption or discussion result so that other analysis result can be made in order to widen idea and opinion (Hancock et al., 2009). Qualitative research is commonly used because the research limitation covering research activity, research data, analyzed variables are there (Yin, 2011). There are five features of qualitative research which are: 1) learning people's life based on real condition, 2) representing view and perspective of people in general, 3) covering someone's contextual condition, 4) contributing idea like the existing concept or the recent concept to explain social attitude 5) using many evidence sources more than personal data sources (Yin, 2011). Qualitative research portrays growing data sources by using particular protocol which is by doing data recording, information analysis, and mentioning scientific approach to record accuracy of the data that have been collected (Creswell, 2013). This present research will be supported by utilizing cognitive model of consumers' attitude comprising of five stages which are 1) looking for recognition and searching for problems, 2) knowing the needs, 3) collecting information, 4) evaluating alternative, and 5) evaluating after buying (Kotler, Amstrong, 2009).

\section{Result and Discussion}

\subsection{Result}

Result of the present research is previous buyers' comments have significant influence on the next buyers. If many buyers give positive comments about a product on e-commerce like Lazada, this can influence the next buyers.

Rating \& Ulasan dari Maxim Wajan Valentino Set - Teflon - Merah-Hitam TULSULASANANDA

Rata-rata penilaian produk

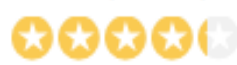

4.3 dari 5

1228 rating 1185 ulasan

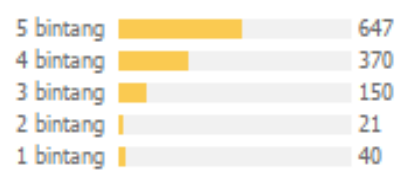

Ulasan Produk

$\bigvee$ Cari berdasarkan: Semua bintang $\quad \uparrow_{\downarrow}$ Atur berdasarkan: Relevan

Fig. 1. Rating and Previous Buyers' Comments (www.Lazada.co.id)

Figure 1 is the example of rating and comment on purchasing a set of cooking tools in form of Valentino Wok Set Teflon which shows rating and previous buyers' comments that feel satisfied buying on Lazada e-commerce. The buyers giving rating 5 stars are 647, 4 stars are 370, 3 stars are 150, 2 stars are 21 and 1 star is 40. These rating and comment can be used by the next buyers to value a product. If many buyers give good rating and comment, this can influence someone's buying decision. These rating and comment can be made as a reference if someone buys the same product. If many buyers give 5 stars rating, it can be made sure that the product is extremely good from every aspects. However, it is different from the product which has less rating and comment as shown in Figure 2. 
Rata-rata penilaian produk

$\begin{array}{lll} & 5 \text { bintang } & 14 \\ 3.2 \text { dari } 5 & 4 \text { bintang } & 10 \\ 49 \text { rating } 48 \text { ulasan } & 3 \text { bintang } & 9 \\ & 2 \text { bintang } & 4 \\ 1 \text { bintang } & 12\end{array}$

Fig. 2. Rating and Previous Buyers' Comments (www.Lazada.co.id)

The product shown on Figure 1 is similar to the product on Figure 2. They have same brand and quality. The difference is Figure 2 offers free stainless steel fried clasps. However, its rating and comment are lower than Figure 1 which is its 5 stars only obtain 14, its 4 stars only obtain 10, its 3 stars get 9, its 2 stars obtain 4, and its 1 star gets 12. This product has the lowest rating and comment score otherwise it has offered bonus of purchasing in form of stainless steel fried clasps.

The researcher finds that there are some factors that influence buying decision, such as price, delivery process, product condition when received, stock of product, and delivery cost. The good delivery that has good rating and comment will keep increasing. The same product with different price will influence buyers' decision. If there are two products with same brand and different price, consumers undeniably expect a product with more affordable price.

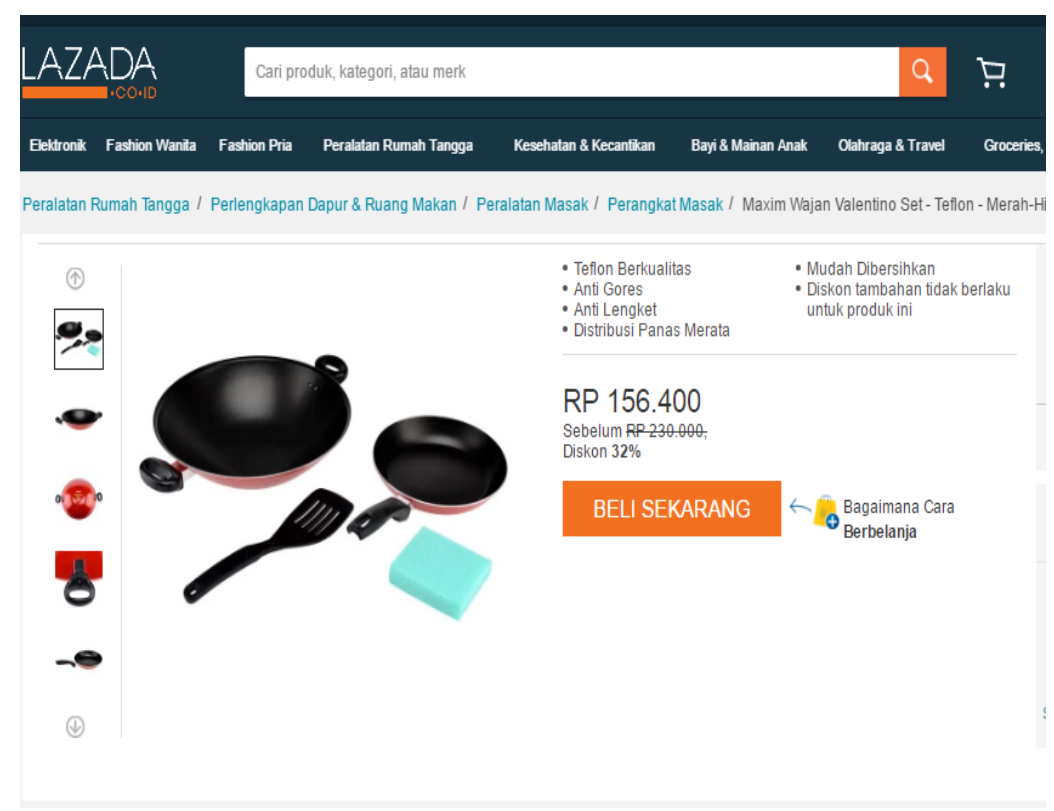

Fig. 3. Maxim Wok Valentino Set - Teflon - Red-Black (www.Lazada.co.id) 


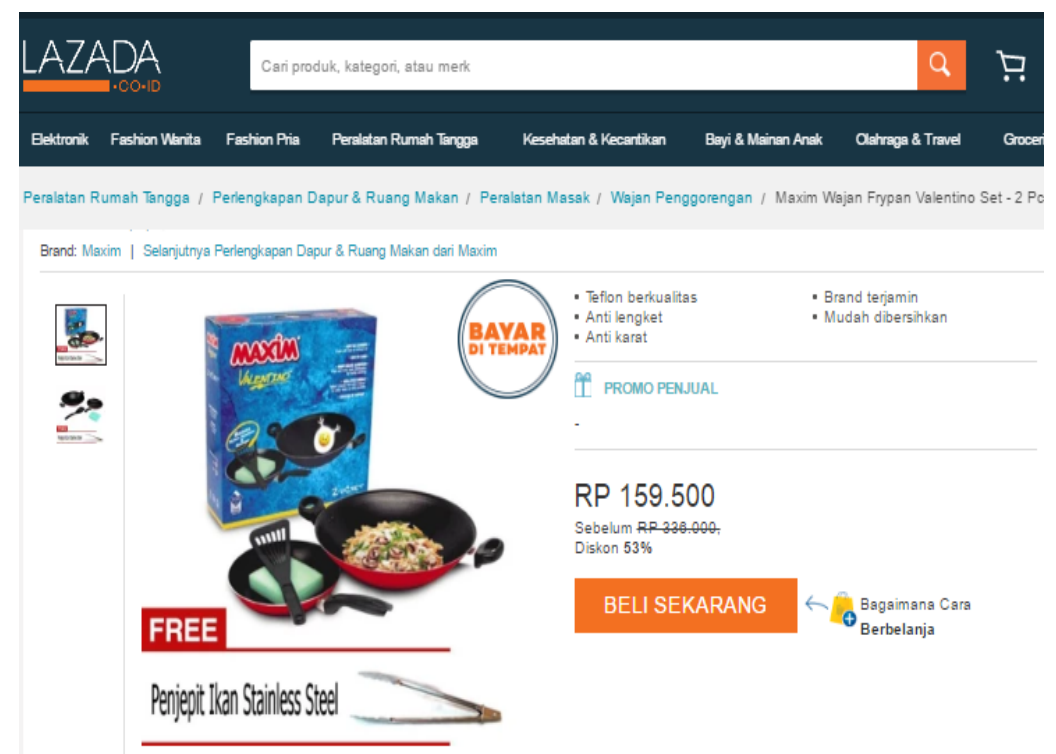

Fig. 4. Maxim Wok Frypan Valentino Set -2 Pcs + Free Stainless Steel Fried Clasps (www.Lazada.co.id)

Figure 3 and 4 have same brands but Figure 3 has more rating and comment. It is caused by product shown on Figure 3 has good product quality with cheaper price which is IDR 158.400, and it has punctual delivery. Figure 4 has many weaknesses such as long-time delivery, product is broken when received, product is not suitable with its description, and product is more expensive which is IDR 159.500. If consumers see two products above, they wil absolutely choose Figure 3 to purchase because it clearly has good rating and comment from previous buyers compared to product on Figure 4.

The results of other researches state that consumers are more interested in product, price, promotion, and service which can increase buyers' interest to purchase a product or a service so that it can support buying decision (Andreti et al., 2013). Product is goods or service offered to consumers which covers six main features which are quality, feature, option, service, warranty, and brand name. Price is amount of money that must be paid to buy or to get goods or service. Promotion is an activity to introduce a product by advertisement and sales. The goal of promotion is the consumers can know the product that is willing to buy better either from benefits aspect or from use aspect. Service is a form of assistance given to consumers, for example assisting the questions and complaints on e-commerce which commonly can be done by calling customer service or by chatting with customer service via online (Ehmke et al.,2005).

\subsection{Discussion}

\subsubsection{Looking for Recognition and Searching for problems}

Before purchasing a product, recognition and problems search must be done in online selling and purchasing in order to minimize problems when it occurs. Recognition, in this case, is a product or a service that has been bought previously (Hawkins et al., 2001). A product that has been purchased or used by other people is something that is expected and it can increase and activate the process of decision making (Engel et al., 1995). Recognition can be found on some social media, websites, advertisements, and recommendations from other people (Kim \& Srivastava, 2007). Recognition occurs because there is a trust from previous buyers who do transaction on Lazada. On e-commerce, trust is stimulous information that can be used to evaluate information on e-commerce. If consumers have had trusts on Lazada, then other consumers will give trusts as well (Punj, 2012). Besides, e-commerce must have good reputation on many social media in order that promotion gets worthy recognition from consumers. Reputation is an image of 
a product or a company from value accumulation conducted by a group of society or consumers (Widiyanto \& Prasilowati, 2015).

After recognition on a product is obtained, then searching for problems that occur on selling and purchasing process must be done. If problem indications are found before buying a product, then it can decrease someone's interest in making decision (Chen-Yu, 1995). The problems that frequently occur on e-commerce are stock of product, buyers' comments regarding to products, new products or new services, geographical condition, technological condition, and the existence of new technology in designing a product (Munthiu, 2009). On Lazada e-commerce, the problems that possibly occur are: the product is out of stock but it is shown available on it, the refund that takes long time, the return of product because it is not same as what is shown on it, and product is broken when delivery.

\subsubsection{Knowing the Needs}

In purchasing a product, the significance to buy the product must be considered first. Knowing the needs is a perception between difference and condition that can increase process of decision making (Engel et al., 1995). The condition that must be counted cover social condition, cultural condition, and economy condition. Consumers must be able to recognize the available consumption choice and be able to value their choices in right ways (Schiffman, Kanuk, 2007). Identifying other needs when purchasing a product will influence other needs purchasing or not (Schiffman \& Kanuk, 2014). Buyers must seriously need that product to make sure that buying decision that is made is in line with their needs (Engel et al., 1995). Decision in recognizing the needs are based on willingness and value of product use if it has been owned (Hawkins et al., 2001). Other considerations in recognizing needs refer to current situation in their life, for instance consumer has three children, consumer wants to buy house and car, debt, income, and education fee (Ponder, 2013).

\subsubsection{Collecting Information}

After knowing the needs, the next phase is collecting information both from external and from internal. Internal information is obtained from e-commerce website of Lazada, while external information is obtained from social media and other websites discussing about Lazada e-commerce (Reynolds \& Olson, 2001). External information also can be obtained from advertisement, friends or other people who have purchased on Lazada (Hogg et al., 2006). Information which is extremely helpful in determining decision is information about price, brand, service, rating and product review.

If in collecting information, buyer gets affordable price, good quality of brand, prime service, and good rating and comment, then it will strengthen someone's decision in buying a product. In collecting information, sometimes information is obtained intentionally or unintentionally. Discovering relevant information will come along with other alternative findings (Hogg et al, 2006). Collecting information is done to minimize risk of purchasing. Commonly, people will prefer buying a product based on the rank of the best comment (Kim \& Srivastava 2007).

\subsubsection{Evaluating Alternative}

After finding information that is expected, a buyer will evaluate alternative of product that will be bought (Reynolds, Olson, 2001). On Lazada, there are so many similar product sellers with some different prices so that it can be made as alternatives. In evaluating alternative, consumers must have attitude and belief. The belief means that the buyer has had guidance in determining the product choice that is willing to buy (Kotler, Armstrong, 2008). The factors that influence alternative evaluation are 1) buying experience of consumers, 2) services and perspectives of product, 3) transaction costs, 4) complexity of evaluated alternatives, 5) the importance of decision making, 6) consumers' risks, 7) environment condition, and 8) attitude (Munthiu, 2009; Dillon, Reif, 2004). Consumer may find alternative of purchasing on other e-commerces because consumer, in this case, finds out which product is the best. Then, after alternative evaluation is done, the next step is choose product and purchase (Solomon, 2014). 


\subsubsection{Evaluating for Buying}

From the process of purchasing until the product is delivered successfully to consumers, it absolutely will go through selling and purchasing transaction in accordance with system used by ecommerce. Not all transaction runs well, there is also a possibility that the product is out of stock and it is refund, or product is not suitable with the description on website. If buyers feel satisfied or not, they will involve in a discussion to give their opinions (Kim, Srivastava 2007). In the case of evaluating after buying, company can influence customers' satisfaction by more flexible refund and product. On the other hand, to minimize negative comments on the delivered product, it must have good quality in line with description, free delivery cost, delivery punctuality, and courier who delivers the product in a friendly way (Kuksov, Xie, 2008). When buyer finds more affordable price than price that must be paid on the same product in this evaluation phase, then it will shift all consumers to that more affordable price product, (Kuksov, Xie, 2008). It is due to the reason that Lazada provides many sellers with the same products and brands with different qualities.

\section{Conclusion}

Product buying decision can occur because there are some processes that must be undergone before making decision which are: looking for recognition and searching for problems, knowing the needs, collecting information, evaluating alternative, and evaluating after buying. In those stages, buying decision on e-commerce is supported by price, promotion, service, and brand. The result of this present research is the previous buyers' comments have significant influence on the next buyers. If previous buyers give postive comments on a product on e-commerce like Lazada, it can influence the next buyers. It is shown on analysis result revealing that product which has many ratings and comments will motivate other buyers to purchase or to obtain the product. If a product has less rating and many negative comments, it will make an assumption that it is not good to buy because there have been many buyers who feel unsatisfied in using the product.

\section{References}

Andreti et al., 2013 - Andreti, J., Zhafira, N. H., Akmal, S. S., \& Kumar, S. (2013). The analysis of product, price, place, promotion and service quality on customers' buying decision of convenience store: A survey of young adult in Bekasi, West Java, Indonesia. International Journal of Advances in Management and Economics, 2(6), 72-78.

Awais \& Samin, 2012 - Awais, M., \& Samin, T. (2012). Advanced SWOT Analysis of Ecommerce. IJCSI International Journal of Computer Science, 9(2), 1694-0814.

Best, 2013 - Best, R. J. (2013). Market-based management, strategies for growing customer value and profitability. New Jersey: Pearson Education, Inc.

Bhalekar et al., 2014 - Bhalekar, P., Ingle, S., \& Pathak, K. (2014). The Study of Ecommerce. Asian Journal of Computer Science \& Information Technology, 4(3).

Chairunnisa, Irwansyah, 2016 - Chairunnisa, S. \& Irwansyah. (2016). An Analysis of Public's Interest in Using Lazada and Tokopedia Ecommerce Services. International Journal of Computer Networks and Wireless Communications, 6(6), 29-34.

Chen-Yu, 1995 - Chen-Yu, H. J. (1995). Consumer Satisfaction/Dissatisfaction with the Performance of Ready-to-Wear Apparel Products. Unpublished doctoral dissertation, University of Minnesota, Saint Paul.

Creswell, 2013 - Creswell, J. W. (2013). Research design: Qualitative, quantitative, and mixed methods approaches. Sage publications.

Dillon, Reif, 2004 - Dillon, T. W., \& Reif, H. L. (2004). Factors influencing consumers'ecommerce commodity purchases. Information Technology, Learning, and Performance Journal, 22(2), 1-12.

Ehmke et al., 2005 - Ehmke, C., Fulton, J., \& Lusk, J. (2005). Marketing's Four P's: First Steps for New Entrepreneurs. Purdue University, Purdue Extension.

Engel et al., 1995 - Engel, J.F, Blackwell, R.D, \& Miniard, P.W. (1995). Consumer behavior. International ed. Florida. Dryden. FIRAT, AF. 1985. A critique of the orientations in theory development in consumer behavior: suggestions for the future. Advances in Consumer Research XXII:3-6. Fifteenth Annual Conference. New Orleans. Association for Consumer Research. 
Gangeshwer, 2013 - Gangeshwer, D. K. (2013). E-commerce or Internet Marketing: A business Review from Indian context. International Journal of u-and e-Service, Science and Technology, 6(6), 187-194.

Gao, 2016 - Gao, J. (2016). Introduction to e-commerce. http://www.engr.sjsu.edu/gaojerry/course/cmpe296u/296z/introduction.pdf

Hancock et al., 2007 - Hancock B., Windridge K., \& Ockleford, E. (2007). An Introduction to Qualitative Research. The NIHR RDS EM / YH.

Hawkins et al., 2001 - Hawkins, W.E., Clark, M.S., Shima, A., Walter, R.B., Winn, R.N., \& Westerfield, $M$. (2001). Four resource centers for fishes: specifies, stocks, and services. Mar Biotechnol (NY) 3: S239-S248.

Hogg et al., 2006 - Hogg, M., Askegaard, S., Bamossy, G., \& Solomon, M. (2006). Consumer behaviour: a European perspective.

www.Lazada.co.id - http://www.Lazada.co.id/maxim-wajan-frypan-valentino-set-2-pcsgratis-penjepit-gorenganstainless-steel-6487357.html

www.Lazada.co.id - https://www.Lazada.co.id/maxim-teflon-valentino-set-frypan-22-cmwok-30-cm-merah-5035444.html?spm=a204j.home.0.0.V8b4KH

Kim, Srivastava, 2007 - Kim , Y., \& Srivastava, J. (2007, August). Impact of social influence in e-commerce decision making. In Proceedings of the ninth international conference on Electronic commerce (pp. 293-302). ACM.

Kotler \& Armstrong, 2008 - Kotler P. \& Armstrong G. (2008). Principles of Marketing, Pearson Prentice Hall, New Jersey.

Kotler \& Armstrong, 2009 - Kotler, P. \& Armstrong, G. (2009). Principles of Marketing. Pearson Education. Thirteenth Edition. New Jersey.

Kuksov \& Xie, 2008 - Kuksov, D., \& Xie, Y. (2008). Pre-and Post-Purchase Management of Customer Satisfaction. Washington University in St. Louis, 19(1), 1-36.

McCole et al., 2010 - McCole, E, Ramsey, E. \& Williams, J. (2010) Trust considerations on attitudes towards online purchasing: the moderating effect of privacy and security concerns. Journal of Business Research, 63, 9-10, pp. 1018-1024.

Munthiu, 2009 - Munthiu, M. C. (2009). The buying decision process and types of buying decision behaviour. Sibiu Alma Mater University Journals, 2(4).

Ponder, 2013 - Ponder, N. (2013). Consumer attitudes and buying behavior for home furniture. Report prepared for the Furniture Outreach Program at Franklin Furniture Institute, Starkville, Mississippi, USA.

Punj, 2012 - Punj, G. (2012). Consumer decision making on the web: A theoretical analysis and research guidelines. Psychology \& Marketing, 29(10), 791-803.

Reynolds \& Olson, 2001 - Reynolds, T. J., \& Olson, J. C. (Eds.). (2001). Understanding consumer decision making: The means-end approach to marketing and advertising strategy. Psychology Press.

Schiffman \& Kanuk, 2004 - Schiffman, L. G., \& Kanuk, L. L. (2004). Consumer behavior. Upper Saddle River, NJ: Pearson Prentice Hall.

Schiffman \& Kanuk, 2007 - Schiffman, L. G., \& Kanuk, L. L. (2007). Consumer Behavior. 9th ed. New Jersey: Prentice Hall

Shim et al., 2002 - Shim, J. P., Shin, Y. B., \& Nottingham, L. (2002). Retailer web site influence on customer shop-ping: An exploratory study on key factors of customer satisfaction. Journal of the Association for Information Systems, 3, 53-76.

Solomon, 2014 - Solomon, M. R. (2014). Consumer behavior: Buying, having, and being (Vol. 10). Engelwood Cliffs, NJ: Prentice Hall.

Widiyanto \& Prasilowati, 2015 - Widiyanto, I., \& Prasilowati, S. L. (2015). Perilaku Pembelian Melalui Internet. Jurnal Manajemen dan Kewirausahaan (Journal of Management and Entrepreneurship), 17(2), 109-122.

Yin, 2011 - Yin, R. K. (2011). Qualitative Research from Start to Finish. New York: The Guilford Press. 